\title{
Test-retest stability of the Pain Catastrophizing Scale and the Tampa Scale for Kinesiophobia in chronic pain patients over a longer period of time
}

Citation for published version (APA):

Lame, I. E., Peters, M. L., Kessels, A. G. H., van Kleef, M., \& Patijn, J. (2008). Test-retest stability of the Pain Catastrophizing Scale and the Tampa Scale for Kinesiophobia in chronic pain patients over a longer period of time. Journal of Health Psychology, 13(6), 820-826. https://doi.org/10.1177/1359105308093866

Document status and date:

Published: 01/01/2008

DOI:

10.1177/1359105308093866

Document Version:

Publisher's PDF, also known as Version of record

Document license:

Taverne

Please check the document version of this publication:

- A submitted manuscript is the version of the article upon submission and before peer-review. There can be important differences between the submitted version and the official published version of record.

People interested in the research are advised to contact the author for the final version of the publication, or visit the DOI to the publisher's website.

- The final author version and the galley proof are versions of the publication after peer review.

- The final published version features the final layout of the paper including the volume, issue and page numbers.

Link to publication

\footnotetext{
General rights rights.

- You may freely distribute the URL identifying the publication in the public portal. please follow below link for the End User Agreement:

www.umlib.nl/taverne-license

Take down policy

If you believe that this document breaches copyright please contact us at:

repository@maastrichtuniversity.nl

providing details and we will investigate your claim.
}

Copyright and moral rights for the publications made accessible in the public portal are retained by the authors and/or other copyright owners and it is a condition of accessing publications that users recognise and abide by the legal requirements associated with these

- Users may download and print one copy of any publication from the public portal for the purpose of private study or research.

- You may not further distribute the material or use it for any profit-making activity or commercial gain

If the publication is distributed under the terms of Article $25 \mathrm{fa}$ of the Dutch Copyright Act, indicated by the "Taverne" license above, 


\section{Test-Retest Stability of the Pain \\ Catastrophizing \\ Scale and the Tampa \\ Scale for \\ Kinesiophobia in \\ Chronic Pain Patients \\ over a Longer Period \\ of Time}

INGE E. LAMÉ

University Hospital Maastricht, The Netherlands

MADELON L. PETERS

University of Maastricht, The Netherlands

ALFONS G. KESSELS, MAARTEN VAN

KLEEF, \& JACOB PATIJN

University Hospital Maastricht, The Netherlands

COMPETING INTERESTS: None declared.

ADDRESS. Correspondence should be directed to:

INGE E. LAMÉ, Pain Management and Research Centre, University Hospital Maastricht, PO Box 5800, 6202 AZ Maastricht, The Netherlands. [Tel. +31 433877498; Fax +31 433875457;

email: ingelame@tiscali.nl:sre@sane.azm.nl

\section{JHP}

Journal of Health Psychology Copyright (C) 2008 SAGE Publications Los Angeles, London, New Delhi and Singapore www.sagepublications.com Vol 13(6) 820-826

DOI: $10.1177 / 1359105308093866$

\section{Keywords}

- chronic pain

- pain

- Pain Catastrophizing Scale

- Tampa Scale for Kinesiophobia

- test-retest stability 


\section{Introduction}

PSYCHOLOGICAL screening measures may be useful in clinical settings to improve the matching of specific treatments to subgroups of pain patients with similar characteristics (Boersma et al., 2004; Crombez, Eccleston, Baeyens, \& Eelen, 1998; de Jong et al., 2005a, 2005b; Vlaeyen, de Jong, Geilen, Heuts, \& van Breukelen, 2001; Vlaeyen, de Jong, Geilen, Heuts, \& van Breukelen, 2002). Due to factors such as waiting lists there may be a delay of weeks to months between screening and a first consultation with the physician. Screening instruments with diagnostic consequences need to be stable over periods of times that are in accordance with this interval between screening and start of treatment. Two instruments that are frequently used for screening psychological aspects of chronic pain are the Pain Catastrophizing Scale (PCS) and the Tampa Scale for Kinesiophobia (TSK). They measure related constructs, pain catastrophizing and pain-related fear. Pain catastrophizing and pain-related fear have emerged as the most reliable psychological predictors of disability and impaired quality of life in chronic pain patients (Lamé, Peters, Vlaeyen, Kleef, \& Patijn, 2005; Sullivan et al., 2002; Vlaeyen, Kole-Snijders, Boeren, \& van Eek, 1995). Although several studies have previously investigated the test-retest stability of the PCS and TSK (Miller, Kori, \& Todd, 1991; Sullivan, Bishop, \& Pivik, 1995; Swinkels-Meewisse, Swinkels, Verbeek, Vlaeyen, \& Oostendorp, 2003; Woby, Roach, Urmston, \& Watson, 2005), none of these studies has examined test-retest stability over an extended period of time in patients with chronic pain. To our best knowledge, test-retest stability of the PCS has only been established once, in the original publication introducing this instrument. Test-retest stability appeared to be adequate $(0.75$ after six weeks and 0.70 after 10 weeks) but this was assessed in a healthy student population (Sullivan et al., 1995). It cannot be ruled out that results will be different for individuals who actually experience pain, compared to those who respond to the questions by imaging how they usually respond to pain.

The presence of pain is essential for pain catastrophizing to become manifest (Keefe et al., 2000; Severeijns, Vlaeyen, van den Hout, \& Picavet, 2005) and pain catastrophizing may vary in time with fluctuating pain intensity. The test-retest stability of the TSK has been assessed in chronic pain patients several times already, but always over relatively short periods of times, varying from 24 hours to eight days
(Miller et al., 1991; Swinkels-Meewisse et al., 2003; Woby et al., 2005). Miller et al. (1991) found a correlation of 0.66 with an interval of eight days, in contrast with the other studies using shorter time intervals, which found correlations close to 0.80 (Swinkels-Meewisse et al., 2003; Woby et al., 2005). When the time interval between the first and second administration is small, a high test-retest correlation could be due to recall. Therefore, the current study explores the test-retest stability of the PCS and TSK in patients with chronic pain complaints using time intervals that reflect common practice in most outpatient pain management facilities.

So far no studies have examined the test-retest stability of the subscales of the PCS and TSK. In previous studies the PCS was found to consist of three subscales: Rumination, Magnification and Helplessness (Osman et al., 2000; Severeijns, van den Hout, Vlaeyen, \& Picavet, 2002; Sullivan et al., 1995; van Damme, Crombez, Bijttebier, Goubert, \& van Houdenhove, 2002). Vlaeyen et al. (1995) examined the factor structure of the TSK and identified a fourfactor model, with the subscales Harm, Fear of (re)injury, Importance of exercise and Avoidance of activity. However, most recently two subscales of the TSK have been identified, which are called Somatic Focus (SF) and Activity Avoidance (AA) (Clark, Kori, \& Brockel, 1996). These were confirmed in subsequent studies (Clark et al., 1996; Geisser, Hang, \& Theisen, 2000; Goubert et al., 2004; Roelofs, Goubert, Peters, Vlaeyen, \& Crombez, 2004). Moreover, these studies indicated that the four reversed key items showed weak associations with the total TSK score and that deleting these items increased internal consistency and test-retest stability (Swinkels-Meewisse et al., 2003). The current study additionally explores the test-retest stability of the subscales of the PCS and TSK and the test-retest stability of the total TSK without the four reversed key items in chronic pain patients.

In summary, the objectives of the current study were: (1) to investigate the test-retest stability of the PCS and TSK in chronic pain patients over a longer period of time; (2) to explore the stability of the PCS and TSK subscales.

\section{Methods}

\section{Participants and procedure}

The subjects included in this study belonged to the population of the Out-patient Clinic for Pain and Pain 
Management of the University Hospital in Maastricht in the Netherlands. This population has been described in detail elsewhere. Briefly, it consists of a heterogeneous group of chronic non-malignant pain patients that are characterized by low scores on quality of life and high scores on catastrophizing (Lamé et al., 2005). Questionnaires-including the PCS and TSK-were mailed to each new referral to the Pain Clinic, as part of the standard intake procedure. The questionnaires had to be returned and evaluated before a first appointment was made with the physician. On the day of their first appointment at the clinic, 50 consecutive non-malignant chronic pain patients were asked to fill out a retest of the PCS and the TSK. No treatment had taken place between the first and the second administration. The registration of demographic variables (gender and age) was part of the standard questionnaire.

\section{Measures}

Tampa Scale for Kinesiophobia The Dutch version of the TSK (Miller et al., 1991; Vlaeyen et al., 1995) (originally developed by Miller et al., 1991 ) is a 17-item questionnaire developed to identify fear of (re)injury due to movement or activities. The items are scored on a four-point Likert scale with scoring possibilities ranging from 'strongly disagree' $($ score $=1)$ to 'strongly agree' $($ score $=4)$. The scores on items 4, 8, 12 and 16 are reversed and total scores range from 17 to 68 . High scores indicate more fear of pain/(re)injury due to movement or activities. Two factors were identified, Somatic Focus (SF) (items 3, 5, 6, 7 and 11) and Activity Avoidance (AA) (items 1, 2, 9, 10, 13, 14, 15 and 17) (Goubert et al., 2004; Roelofs et al., 2004). The questionnaire has been validated, with sufficient internal consistency $(\alpha=0.77)$ and validity (Vlaeyen et al., 1995).

Pain Catastrophizing Scale The Dutch version of the PCS (Crombez \&Vlaeyen, 1996; Sullivan et al., 1995) is a 13-item questionnaire developed to identify catastrophic thoughts or feelings in relation to painful experiences. The items are scored on a five-point Likert scale with scoring possibilities ranging from 'not at all' $($ score $=0)$ to 'always' (score $=4$ ). The total score ranges from 0 to 52 and high scores indicate that more catastrophic thoughts or feelings are experienced. Three factors were identified, rumination (items 8, 9, 10 and 11), magnification (items 6, 7 and 13) and helplessness (items 1, 2, 3, 4, 5 and 12) (Sullivan et al.,
1995). The psychometric properties of the PCS appeared adequate. The internal consistency measured in a student sample (Crombez et al., 1998) and in two samples of chronic low back pain patients (van Damme et al., 2000) was adequate (Cronbach's $\alpha=0.85,0.88$ and 0.91 , respectively).

\section{Data analysis}

To calculate differences between the mean PCS and TSK scores of the first and the second administration, Student's $t$ tests were used. The test-retest stability of the PCS, TSK and the subscales was determined with the Intraclass Correlation Coefficient (ICC) (Shrout \& Fleiss, 1979). ICC values above 0.75 indicate good reliability (Nunnally \& Bernstein, 1994) and we defined ICCs between 0.70 and 0.75 as sufficient reliability. The ICCs of the PCS and TSK total scores and subscale scores are mutually statistical dependent. To test for differences between these ICCs, a bootstrap technique was used (Efron \& Tibshiram, 1993). This technique provides a way to obtain confidence intervals and standard deviations when no appropriate formula is otherwise available. Data were analysed by using the SPSS Statistical Package, version 12.0 for Windows and Stata Statistical Package Release 8.

\section{Results}

\section{Description of sample}

Mean age of patients was 54.7 years $(\mathrm{SD}=13.1), 40$ per cent were male (mean age 51.9 years, $\mathrm{SD}=$ 13.2) and 60 per cent female (mean age 56.6 years, $\mathrm{SD}=12.8$ ). Pain duration varied between three months up to 38 years. Seventy-eight per cent of the patients reported musculoskeletal pain, of which 50 per cent suffered from low back pain (LBP). Mean Visual Analogue Scale (VAS) at baseline was 7.2 $(\mathrm{SD}=1.9)$. Forty-eight patients completed the retest of the PCS and 46 patients completed the retest of the TSK. Due to waiting list procedures of our Pain Clinic, the mean test-retest interval was 51.7 days $(\mathrm{SD}=21.7 ;$ median $=44.0 ;$ range 14-135 $)$. There were no significant differences between men $(n=$ $20)$ and women $(n=30)$ in PCS $(p=.41)$ and TSK total scores $(p=.45)$. Baseline and retest information about the PCS and TSK total and subscale scores are presented in Table 1. The scores we found reflect scores that are common in chronic pain populations (Lamé et al., 2005; Vlaeyen et al., 1995). Except for the Magnification subscale of the 
Table 1. Internal consistency (Cronbach's $\alpha$ ), test-retest mean and ICC values of the PCS and TSK total and subscale scores

\begin{tabular}{lllllll}
\hline & & \multicolumn{2}{c}{ First administration } & $\begin{array}{l}\text { Second administration } \\
\text { mean }(S D)\end{array}$ & ICC & 95\% confidence interval \\
& $N$ & Cronbach's $\alpha$ & mean (SD) & $31.4(13.3)$ & 0.73 & $0.56-0.84$ \\
PCS Total & 48 & 0.92 & $30.2(11.7)$ & $10.4(4.2)$ & 0.63 & $0.42-0.78$ \\
Rumination & 47 & 0.84 & $11.1(3.6)$ & $5.3(3.5)^{*}$ & 0.71 & $0.51-0.83$ \\
Magnification & 46 & 0.74 & $4.5(3.3)$ & $15.9(6.1)$ & 0.65 & $0.44-0.79$ \\
Helplessness & 46 & 0.87 & $14.9(5.9)$ & $41.3(9.5)$ & 0.72 & $0.54-0.83$ \\
TSK Total & 46 & 0.73 & $41.0(7.8)$ & $11.3(4.2)$ & 0.67 & $0.47-0.80$ \\
Somatic focus & 47 & 0.73 & $10.7(3.6)$ & $19.3(7.2)$ & 0.68 & $0.49-0.81$ \\
Activity avoidance & 45 & 0.81 & $18.9(5.8)$ & &
\end{tabular}

$* p=.02$

PCS $(p=.02)$ there were no significant differences in total or subscale scores between the first and the second administration. The internal consistency (Cronbach's $\alpha$ ) was sufficient (TSK total score, TSK subscale Somatic Focus and PCS subscale magnification) to good (PCS total score, PCS subscales rumination, helplessness and TSK subscale Activity Avoidance) (Table 1).

\section{Test-retest stability}

The test-retest ICCs of the PCS (0.67) and the TSK (0.63) were moderate. Visualization of the difference between baseline and retest scores plotted against the time interval between both moments, showed a range between -28 and 20 for PCS difference scores and between -12 and 20 for TSK difference scores (difference of retest minus baseline scores) (Fig. 1a and 1b). No relation was found between the ICCs and the length of the interval. After standardizing the dataset ( $z$-scores), two outliers defined as deviating $2.5 \mathrm{SD}$ or more from the mean value were found for both PCS and TSK total scores. ICC improved when the outliers were omitted from the dataset $\left(\mathrm{ICC}_{\mathrm{pcs}}=0.73(n=48)\right.$ and $\left.\mathrm{ICC}_{\text {tsk }}=0.72(n=46)\right)$, now demonstrating sufficient test-retest stability. After omitting the reversed key items of the TSK from the dataset, $\mathrm{ICC}_{\text {tsk }}$ increased slightly to 0.74 (the outliers were omitted from the dataset).

Table 1 summarizes the test-retest stability of the subscales of the PCS and TSK. All ICCs are measured without the outliers. Bootstrap statistics indicated that the test-retest correlation of the TSK subscales did not significantly differ from that of the total TSK. However, for the PCS, test-retest stability of the subscales Rumination $(p=.01)$ and Helplessness $(p=.02)$ were significantly lower than that of the total score, and only magnification proved to have similar test-retest stability.

\section{Discussion}

The main aim of the current study was to investigate the test-retest stability of the PCS and TSK in chronic pain patients over a longer period of time. To establish test-retest stability, we used time intervals between the first and the second administration of screening instruments that reflect common practice in most out-patient pain management facilities. Although the time interval between the baseline and retest measuring moment was quite long and varied considerably between individuals, both $\mathrm{ICC}_{\mathrm{pcs}}$ and $\mathrm{ICC}_{\text {tsk }}$ appeared to be stable over time, especially after removing two patients who appeared to be outliers. There was no relation found between the ICCs and the time interval.

Previously it was found that omitting the reversed key items improved internal consistency (Goubert et al., 2004; Roelofs et al., 2004; SwinkelsMeewisse et al., 2003) and the test-retest stability (Swinkels-Meewisse et al., 2003). However, the current study only found a moderate increase in test-retest stability when omitting the reversed key items. Nevertheless, since the reversed key items often seem to be misinterpreted and patients need to be instructed so that they will be more alert about answering these questions (Roelofs et al., 2004; Swinkels-Meewisse et al., 2003), we recommend that the TSK is used without the reversed key items for screening purposes.

A secondary objective of this study was to explore the test-retest stability of the PCS and TSK subscales. The results indicate that the PCS subscale Magnification has similar test-retest stability to the 


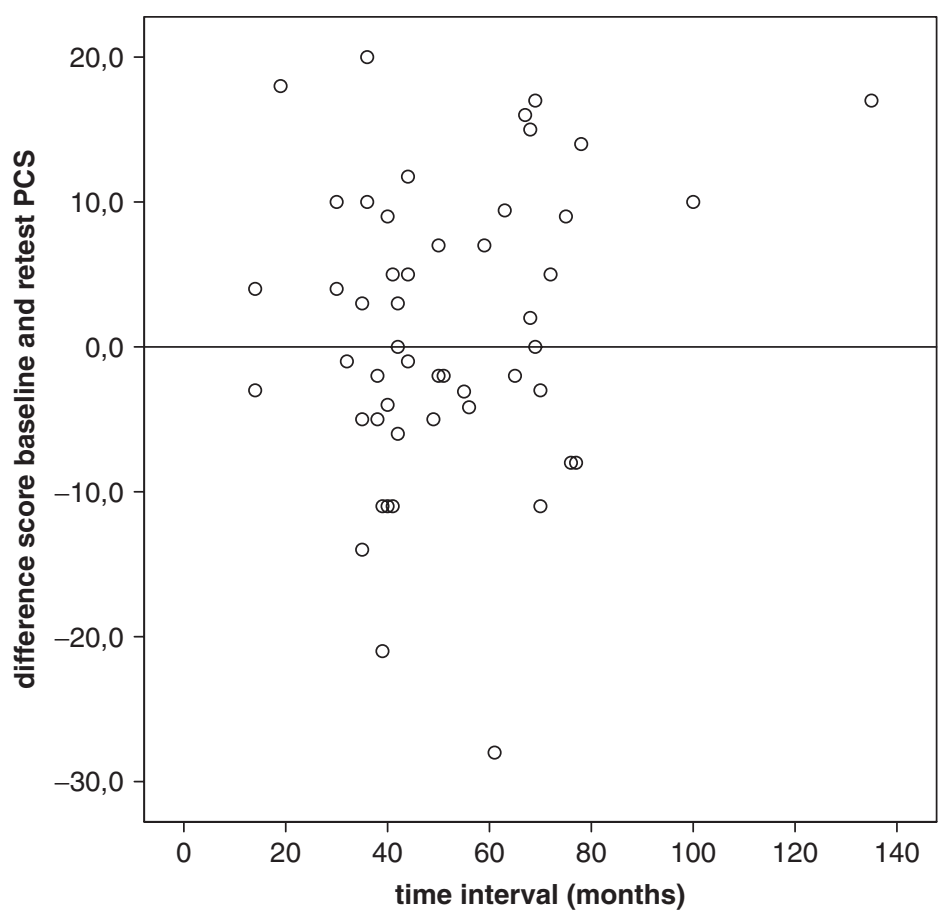

Figure 1a. Scatter plot of differences in retest and baseline PCS scores and the time interval.

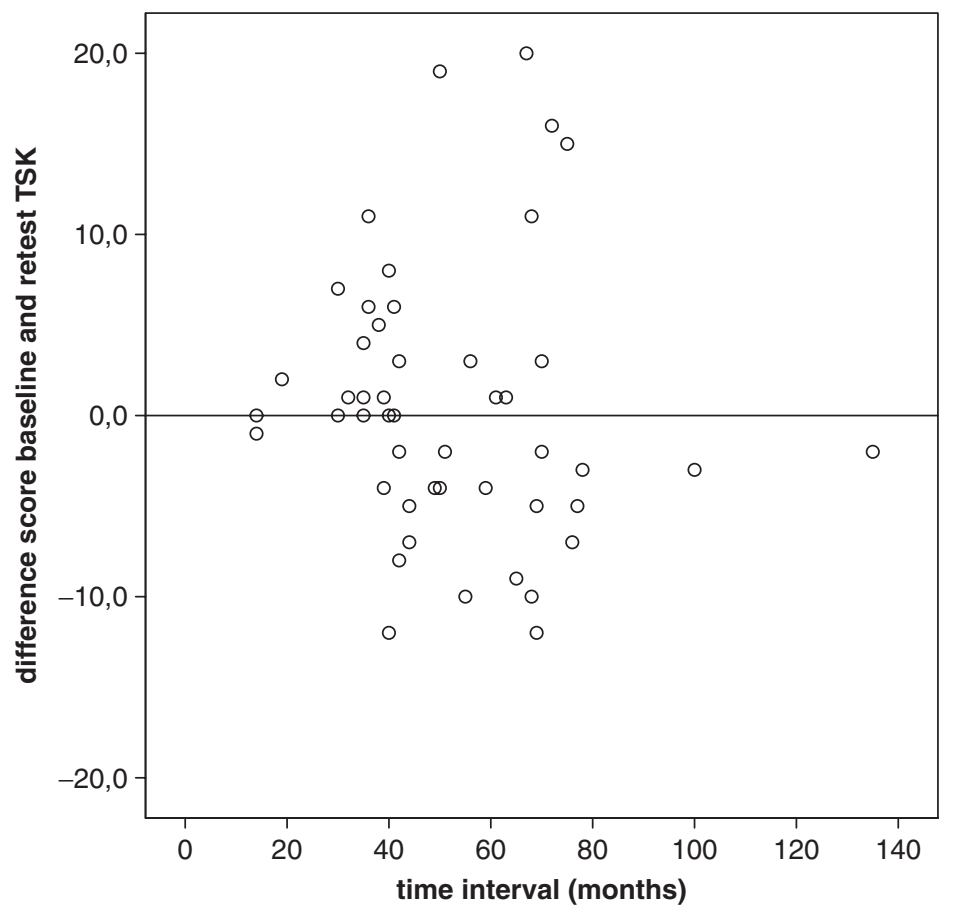

Figure $1 b$. Scatter plot of differences in retest and baseline TSK scores and the time interval. 
PCS total score. However, the subscales Rumination and Helplessness appeared to be less stable in time. Therefore, for screening purposes, the PCS total score is recommended. Indeed, so far the subscales have not often been used. Otherwise, some studies found evidence for both a one-factor model and a three-factor model of the PCS with high correlations between the subscales (Osman et al., 2000; Severeijns et al., 2002). Further research is required to explore whether the predictive validity of the subscales could be guaranteed. Both subscales of the TSK were found to have similar test-retest stability as the total TSK scale. The interrelationship between the two subscales was found to be strong (0.74) (Goubert et al., 2004; Roelofs et al., 2004). However, it remains to be determined whether the two subscales have differential predictive validity and whether one should use both subscales separately for screening purposes or whether the total score suffices.

A limitation of the present study that should be acknowledged is that the sample size is somewhat small. This increases the range of the confidence intervals and the lower limits of these ranges contain ICCs that many would interpret as being poor (e.g. .42). Another limitation is the fact that pain intensity at the second administration was not measured. We assumed that pain intensity remains relatively stable in patients with chronic pain but have not tested this. Furthermore, originally the TSK was developed for use in patients with low back pain. However, recently some studies showed that the TSK has predictive value for pain outcomes in populations with other musculoskeletal pain complaints like osteoarthritis (Heuts et al., 2004; Kvist, Ek, Sporrstedt, \& Good, 2005) and fibromyalgia (Burwinkle, Robinson, \& Turk, 2005; Goubert et al., 2004; Roelofs et al., 2004). Our sample consisted mainly of patients with musculoskeletal pain (78\%), of which 50 per cent reported back pain.

In conclusion, this study suggests that both instruments possess sufficient test-retest stability, over extended period of times, in a clinical population waiting for treatment in a hospital clinic and can be recommended for use as a screening tool to select patients eligible for cognitive behavioural treatment or exposure training to reduce pain catastrophizing and pain-related fear. Nevertheless it is important to remember that although the measure is stable and for most patients scores will not vary greatly over time, in some individuals they will. Therefore, whenever possible, multiple assessments remain preferable.

\section{References}

Boersma, K., Linton, S., Overmeer, T., Jansson, M., Vlaeyen, J., \& de Jong, J. (2004). Lowering fear-avoidance and enhancing function through exposure in vivo: A multiple baseline study across six patients with back pain. Pain, 108(1-2), 8-16.

Burwinkle, T., Robinson, J. P., \& Turk, D. C. (2005). Fear of movement: Factor structure of the Tampa Scale of Kinesiophobia in patients with fibromyalgia syndrome. Journal of Pain, 6(6), 384-391.

Clark, M. E., Kori, S. H., \& Brockel, J. (1996). Kinesiophobia and chronic pain: Psychometric characteristics and factor analysis of the Tampa Scale. American Pain Society Abstract 77.

Crombez, G., Eccleston, C., Baeyens, F., \& Eelen, P. (1998). When somatic information threatens, catastrophic thinking enhances attentional interference. Pain, 75(2-3), 187-198.

Crombez, G., \& Vlaeyen, J. W. S. (1996). The Pain Catastrophizing Scale. Unpublished Dutch/Flemish translation.

De Jong, J. R., Vlaeyen, J. W., Onghena, P., Cuypers, C., den Hollander, M., \& Ruijgrok, J. (2005a). Reduction of pain-related fear in complex regional pain syndrome type I: The application of graded exposure in vivo. Pain, 116(3), 264-275.

De Jong, J. R., Vlaeyen, J. W., Onghena, P., Goossens, M. E., Geilen, M., \& Mulder, H. (2005b). Fear of movement/(re)injury in chronic low back pain: Education or exposure in vivo as mediator to fear reduction? Clinical Journal of Pain, 21(1), 9-17; discussion 69-72.

Efron, B., \& Tibshiram, R. J. (1993). An introduction to the bootstrap. New York: Chapman \& Halk.

Geisser, M. E., Hang, A. J., \& Theisen, M. E. (2000). Activity avoidance and function in persons with chronic back pain. Journal of Occupational Rehabilitation, 10(3), 215-227.

Goubert, L., Crombez, G., van Damme, S., Vlaeyen, J. W., Bijttebier, P., \& Roelofs, J. (2004). Confirmatory factor analysis of the Tampa Scale for Kinesiophobia: Invariant two-factor model across low back pain patients and fibromyalgia patients. Clinical Journal of Pain, 20(2), 103-110.

Heuts, P. H., Vlaeyen, J. W., Roelofs, J., de Bie, R. A., Aretz, K., van Weel, C., \& van Schayck, O. C. (2004). Pain-related fear and daily functioning in patients with osteoarthritis. Pain, 110(1-2), 228-235.

Keefe, F. J., Lefebvre, J. C., Egert, J. R., Affleck, G., Sullivan, M. J., \& Caldwell, D. S. (2000). The relationship of gender to pain, pain behavior, and disability in osteoarthritis patients: The role of catastrophizing. Pain, 87(3), 325-334.

Kvist, J., Ek, A., Sporrstedt, K., \& Good, L. (2005). Fear of re-injury: A hindrance for returning to sports after anterior cruciate ligament reconstruction. Knee Surgery, Sports Traumatology, Arthroscopy, 13(5), 393-397. 
Lamé, I. E., Peters, M. L., Vlaeyen, J. W., Kleef, M., \& Patijn, J. (2005). Quality of life in chronic pain is more associated with beliefs about pain, than with pain intensity. European Journal of Pain, 9(1), 15-24.

Miller, R. P., Kori, S. H., \& Todd, D. D. (1991). The Tampa Scale for Kinesiophobia. Unpublished report.

Nunnally, J., \& Bernstein, I. (1994). Psychometric theory. New York: McGraw Hill.

Osman, A., Barrios, F. X., Gutierrez, P. M., Kopper, B. A., Merrifield, T., \& Grittmann, L. (2000). The Pain Catastrophizing Scale: Further psychometric evaluation with adult samples. Journal of Behavioral Medicine, 23(4), 351-365.

Roelofs, J., Goubert, L., Peters, M. L., Vlaeyen, J. W., \& Crombez, G. (2004). The Tampa Scale for Kinesiophobia: Further examination of psychometric properties in patients with chronic low back pain and fibromyalgia. European Journal of Pain, 8(5), 495-502.

Severeijns, R., van den Hout, M. A., Vlaeyen, J. W., \& Picavet, H. S. (2002). Pain catastrophizing and general health status in a large Dutch community sample. Pain, 99(1-2), 367-376.

Severeijns, R., Vlaeyen, J. W., van den Hout, M. A., \& Picavet, H. S. (2005). Pain catastrophizing and consequences of musculoskeletal pain: A prospective study in the Dutch community. Journal of Pain, 6(2), 125-132.

Shrout, P. E., \& Fleiss, J. L. (1979). Intraclass correlations: Uses in assessing rater reliability. Psychological Bulletin, 86(2), 420-428.

Sullivan, M. J. L., Bishop, S. R., \& Pivik, J. (1995). The Pain Catastrophizing Scale: Development and validation. Psychological Assessment, 7(4), 524-532.

Sullivan, M. J., Rodgers, W. M., Wilson, P. M., Bell, G. J., Murray, T. C., \& Fraser, S. N. (2002). An experimental investigation of the relation between catastrophizing and activity intolerance. Pain, 100(1-2), 47-53.

Swinkels-Meewisse, E. J. C. M., Swinkels, R. A. H. M., Verbeek, A. L. M., Vlaeyen, J., \& Oostendorp, R. A. B. (2003). Psychometric properties of the Tampa Scale for Kinesiophobia and the fear-avoidance beliefs questionnaire in acute low back pain. Manual Therapy, 8(1), 29-36.

Van Damme, S., Crombez, G., Bijttebier, P., Goubert, L., \& van Houdenhove, B. (2002). A confirmatory factor analysis of the Pain Catastrophizing Scale: Invariant factor structure across clinical and non-clinical populations. Pain, 96(3), 319-324.

Van Damme, S., Crombez, G., Vlaeyen, J., Goubert, L., van den Broeck, A., \& van Houdenhove, B. (2000). De Pain Catastrophizing Scale: Psychometrische karakteristieken en normering. Gedragstherapie, 3, 211-222.

Vlaeyen, J. W., de Jong, J., Geilen, M., Heuts, P. H., \& van Breukelen, G. (2001). Graded exposure in vivo in the treatment of pain-related fear: A replicated single-case experimental design in four patients with chronic low back pain. Behaviour Research and Therapy, 39(2), 151-166.

Vlaeyen, J. W., de Jong, J., Geilen, M., Heuts, P. H., \& van Breukelen, G. (2002). The treatment of fear of movement/(re)injury in chronic low back pain: Further evidence on the effectiveness of exposure in vivo. Clinical Journal of Pain, 18(4), 251-261.

Vlaeyen, J. W., Kole-Snijders, A. M., Boeren, R. G., \& van Eek, H. (1995). Fear of movement/(re)injury in chronic low back pain and its relation to behavioral performance. Pain, 62(3), 363-372.

Woby, S. R., Roach, N. K., Urmston, M., \& Watson, P. J. (2005). Psychometric properties of the TSK-11: A shortened version of the Tampa Scale for Kinesiophobia. Pain, 117(1-2), 137-144.

\section{Author biographies}

INGE E. LAMÉ, MSc, is researcher in the Pain Management and Research Centre, University Hospital, Maastricht. She undertakes research on a project of psychological predictors of treatment outcome in chronic pain.

MADELON L. PETERS, PhD, is Professor of Experimental Health Psychology at Maastricht University, Faculty of Psychology, Maastricht. Her major research area is psychological factors in chronic pain.

ALFONS G. H. KESSELS, MD, MSc, is epidemiologist/ statistician in the Department of Clinical Epidemiology and Medical Technology Assessment, University Hospital, Maastricht.
MAARTEN VAN KLEEF, MD, PhD, FIPP, is Professor and chairman of the department of Anaesthesiology and Pain Management, University of Maastricht. He is a Member of the Board of the World Institute of Pain and Vice-chairman of the examination board of the World Institute of Pain. His special field of interest is research on mechanisms and outcome of pain interventions.

JACOB PATIJN, MD, PhD, is a Neurologist and Head of the Pain Management and Research Centre, University Hospital, Maastricht. His special fields of interest are research in pain medicine and musculoskeletal medicine. 